Research Article

\title{
The Protective Impact of Black Chokeberry Fruit Extract (Aronia melanocarpa L.) on the Oxidoreductive System of the Parotid Gland of Rats Exposed to Cadmium
}

\author{
Zofia Dąrowska $\left({ }^{D},{ }^{1}\right.$ Ewa Dabrowska, ${ }^{2}$ Barbara Onopiuk $\left(D,{ }^{3}\right.$ Paweł Onopiuk, ${ }^{4}$ \\ Karolina Orywal, ${ }^{5}$ Barbara Mroczko $₫{ }^{5}{ }^{5}$ and Malgorzata Pietruska ${ }^{6}$ \\ ${ }^{1}$ Medical University of Bialystok, M. Skłodowskiej-Curie 24 A, Bialystok 15-276, Poland \\ ${ }^{2}$ Department of Gerostomatology of Medical University of Białystok, ul. Akademicka 3, Białystok 15-286, Poland \\ ${ }^{3}$ Medical University of Białystok and Private Dental Office in Białystok, ul. Rzemieślnicza 37, Białystok 15-773, Poland \\ ${ }^{4}$ Otholaryngology Department, Medical University of Białystok, M. Skłodowskiej-Curie 24 A, Białystok 15-276, Poland \\ ${ }^{5}$ Department of Biochemical Diagnostics, Medical University of Bialystok, ul. Waszyngtona 15A, Białystok 15-269, Poland \\ ${ }^{6}$ Department of Periodontology, Medical University of Białystok, ul. Waszyngtona 13, Białystok 15-269, Poland
}

Correspondence should be addressed to Barbara Onopiuk; barbara.maria.dabrowska@gmail.com

Received 7 August 2019; Revised 26 September 2019; Accepted 4 November 2019; Published 23 November 2019

Guest Editor: Rosa M. López-Pintor

Copyright (c) 2019 Zofia Dąbrowska et al. This is an open access article distributed under the Creative Commons Attribution License, which permits unrestricted use, distribution, and reproduction in any medium, provided the original work is properly cited.

\begin{abstract}
Cadmium (Cd) is a strongly toxic heavy metal with prooxidative properties. Since the exposure of the general population to this metal is predicted to increase, effective methods are being sought to prevent its negative actions. One of them involves the use of the antioxidant potential of polyphenol compounds contained in black chokeberry fruit extract and their capability of complex formation with $\mathrm{Cd}^{2+}$. The study objective was to investigate whether the administration of A. melanocarpa fruit extract rich in polyphenol compounds during low and moderate exposures to cadmium can protect the parotid gland against oxidative damage. The study was conducted using the experimental model on female Wistar rats which were given $0.1 \%$ aqueous extract of Aronia melanocarpa fruit (AE) and/or cadmium at a concentration of $1\left(\mathrm{Cd}_{1}\right)$ or $5\left(\mathrm{Cd}_{5}\right) \mathrm{mg} \mathrm{Cd} / \mathrm{kg}$ feed for 3 and $10 \mathrm{months}$, and on control animals. The exposure to $\mathrm{Cd}$ attenuated the enzymatic antioxidant barrier (catalase (CAT), superoxide dismutase (SOD), glutathione peroxidase $(\mathrm{GPx})$ ) and increased the concentration of hydrogen peroxide $\left(\mathrm{H}_{2} \mathrm{O}_{2}\right)$, protein carbonyl (PC) groups, and oxidized lipids (LPO) in parotid gland. These disorders led to a reduction in the total antioxidative status (TAS), an increase in the total oxidative state (TOS), and development of stress. The administration of AE at both levels of exposure to cadmium substantially improved the enzymatic antioxidant barrier (CAT, SOD, GPx) and prevented oxidative damage to cellular macromolecules (PC, LPO) and the increase in the level of $\mathrm{H}_{2} \mathrm{O}_{2}, \mathrm{MPO}$, TOS, and stress indicator $(\mathrm{OSI}=\mathrm{TOS} / \mathrm{TAS})$ in the parotid gland. Concluding, it should be stated that the consumption of aronia products may prevent oxidative/antioxidative imbalance induced by $\mathrm{Cd}$ and oxidative stress development in the parotid gland, thus protecting the gland from damage.
\end{abstract}

\section{Introduction}

Cadmium (Cd) occupies the top place in the group of toxic metals and its harmful effects in living organisms have been relatively well known. The results reported in recent years have provided evidence that even low chronic exposure to this metal is hazardous to health [1-4]. The effects of expo- sure to cadmium involve damage to numerous tissues and organs, including the kidneys $[5,6]$, liver $[7,8]$, bone system $[9,10]$, cardiovascular system $[11,12]$, and contribute to the development of neoplastic diseases $[13,14]$ and oral disorders [15-17]. Smoking is the primary source of Cd exposure, especially in relation to oral health, mainly in people living in the areas with low level of cadmium pollution and no 
occupational exposure. The effect of the $\mathrm{Cd}$ in tobacco on oral mouth is gingival pigmentation, darkening teeth, slow regeneration of the soft tissues, and dysphagia [18, 19].

The ability of Cd to induce oxidative stress is one of the main toxic mechanisms affecting the body. The mechanism of stress development in conditions of exposure to cadmium is multidirectional [20-23]. The $\mathrm{Cd}^{2+}$ ions do not exhibit the ability to directly generate reactive oxygen species (ROS), but they may cause oxidative damage to numerous tissues and organs, including the salivary glands via intermediate mechanisms (attenuation of the protective antioxidant barrier, reduced thiol status, and release of transitory metal ions) [20, 22, 24-30].

The effect of $\mathrm{Cd}$ on salivary gland tissue has not been studied so extensively as its other effects and it is thus not fully elucidated. The available findings, however, indicate that the exposure to this metal may lead to functional lesions and structural damage to the salivary glands, what was shown in authors' previous research [31-33]. Moreover, it may be the consequence of, e.g., its prooxidative effect $[27,28]$.

Due to high toxicity of cadmium, its wide spread in the environment, and the prognosis that its exposure among the general population is going to increase $[1,2]$, a search has been conducted for the effective methods to prevent health effects of the exposure, especially its deleterious effect on the parotid gland tissue. Natural substances with their antioxidant properties should be considered, including polyphenol compounds commonly encountered in the products of plant origin, to effectively prevent the impact of the prooxidative influence of cadmium (Cd) exposure [22, 26, 34-38]. The antioxidant properties of polyphenol compounds result to a large extent from the presence of hydroxyl groups $(-\mathrm{OH})$ in their molecules, which are able to form metal ion complexes, e.g., of cadmium, and to inactivate free radicals and reactive oxygen species [37, 39].

Black chokeberry fruits are among the richest sources of these compounds $[22,35]$. The available data indicate that the administration of A. melanocarpa extract decreases cadmium accumulation in the body and protects from damage to the bone structure and liver $[21,26,29,30]$. Therefore, and regarding its high antioxidant potential [35-37], the extract may also be assumed to protect against the development of oxidative stress in the parotid gland.

\section{Aim}

In the current study, we aimed to determine the possible protective effect of A. melanocarpa fruit extract on the rat parotid gland in conditions of low and moderate exposures to cadmium.

\section{Materials and Methods}

3.1. Black Chokeberry Fruit Extract. Extract of AMP was received from Adamed Consumer Healthcare (Tuszyn, Poland). According to the producer, the extract contained $65.74 \%$ of polyphenols, including $18.65 \%$ of anthocyanins (Certificate KJ 4/2010; Butch No. M100703). The total polyphenol content in the powdered AMP extract assayed by us (according to the colorimetric Folin-Ciocalteu method described by Tawaha et al.) [40] reached $61.24 \pm 0.01 \%$ (mean $\pm \mathrm{SD})$.

Extracts of AMP compounds are anthocyanins, proanthocyanidins (oligomeric and polymeric catechins), flavonols (glycoside derivatives of quercetin), and hydroxycinnamic acids (chlorogenic and neochlorogenic acids). The anthocyanin profile of Aronia melanocarpa consists almost exclusively of cyanidin glycosides, namely, cyanidin-3-arabinoside, cyanidin-3-galactoside, cyanidin-3-glucoside, and cyanidin-3-xyloside (the first two are predominant), and relatively low amounts of pelargonidin-3-arabinoside and pelargonidin-3-galactoside. Flavonols were identified as the minor class of polyphenols in chokeberries. Quercetin, kaempferol, and several quercetin mono- and diglycosides (quercetin-3-galactoside, quercetin-3-glucoside, quercetin3-rutinoside, quercetin 3-vicianoside, and quercetin-3-robinobioside) were also detected in aronia berries, but in relatively low concentrations. Chokeberry proanthocyanidins consist exclusively of (-)-epicatechin units bonded by a $\mathrm{C} 4$ to C8 linkage. The hydroxycinnamic acids are represented by significant amounts of chlorogenic and neochlorogenic acids $[41,42]$.

3.2. Animals and Experimental Protocol. The parotid salivary glands of the rats used in the current study were collected and secured during an experiment conducted in the Department of Toxicology, Medical University of Białystok. The study was approved by the Local Ethics Committee for Experiments on Animals in Białystok, nr 60/2009.

The experiment was conducted on 96 young (3-4-weekold) female Wistar [Crl: WI (Han)] rats with an initial body weight of approximately $50 \mathrm{~g}$. The animals were kept in stainless steel cages in standard breeding conditions (relative humidity $50 \pm 10 \%$, temperature $22 \pm 2^{\circ} \mathrm{C}, 12$-hour cycle) throughout the experiment. The rats were divided randomly into 6 experimental groups.

The animals were randomized into 6 study groups of 16 :

Group 1-control: throughout the experiment (3 or 10 months), the rats received purified water and standard fodder (Labofeed, Kcynia)

Group 2-AMPF: the rats received only a $0.1 \%$ water solution of extract of polyphenols (AMPF) for drinking for 3 or 10 months and standard fodder

Group 3- $\mathrm{Cd}^{1}$ : the rats were exposed to cadmium (as $\mathrm{CdCl}_{2}$ ) in the fodder, receiving $1 \mathrm{mg} \mathrm{Cd} / \mathrm{kg}$ for 3 or 10 months, and received purified water for drinking Group 4- $\mathrm{Cd}_{1}+$ AMPF: throughout the period (3 or 10 months) of exposure to $1 \mathrm{mg}$ of $\mathrm{Cd} / \mathrm{kg}$, the rats received the $0.1 \%$ water solution of extract of polyphenols from black chokeberry fruit

Group 5- $\mathrm{Cd}^{5}$ : the rats received fodder containing $5 \mathrm{mg}$ $\mathrm{Cd} / \mathrm{kg}$ for 3 or 10 months and purified water for drinking

Group 6- $\mathrm{Cd}_{5}+$ AMPF: during exposure (for 3 or 10 months) to $5 \mathrm{mg} \mathrm{Cd} / \mathrm{kg}$ of fodder, the rats received $0.1 \%$ water solution of extract of polyphenols from black chokeberry fruit for drinking

The powdered black chokeberry fruit extract was obtained from Adamed Consumer Healthcare (Tuszyn, 
Poland), which according to the producer contained $65.74 \%$ of polyphenol compounds, including $18.65 \%$ of anthocyanins. Polyphenolic compounds and cadmium were administered orally. By administering a $0.1 \%$ polyphenol's extract water solution from black chokeberry fruit, it was ensured that the rats would consume no less than $51.7-104.6 \mathrm{mg} / \mathrm{kg}$ of body weight, depending on the age of the animal.

AMP were administered in the form of a $0.1 \%$ aqueous extract of these compounds from the aronia berries administered as the only drinking fluid. This fluid was prepared daily by dissolving the appropriate amount of the powdered AMP extract in appropriate volume of redistilled water ( $1 \mathrm{~g}$ of the extract per litter of redistilled water). Polyphenol concentration, determined by us (as reported by Tawaha et al. [40]), in such prepared formulation was stable during $24 \mathrm{~h}$ and reached $0.612 \pm 0.006 \mathrm{mg} / \mathrm{mL}$ (mean $\pm \mathrm{SD}$ ). The last group of rats, that drank water without AMP addition and was feed with the standard Labofeed diets without $\mathrm{Cd}$ (Labofeed $\mathrm{H}$ and $B$ diets), served as a control. Redistilled water (containing $<0.05 \mu \mathrm{g} \mathrm{Cd} / \mathrm{L}$ and not completely deprived of necessary bioelements) was used as drinking water to eliminate $\mathrm{Cd}$ intake in the control group and AMP group, and additional Cd consumption in the animals exposed to this metal. Cd concentration in the standard Labofeed $\mathrm{H}$ and $\mathrm{B}$ diets (without $\mathrm{Cd}$ addition) did not differ and reached $0.0584 \pm 0.0049$ $\mathrm{mg} / \mathrm{kg}$ (mean $\pm \mathrm{SD}$ ), whereas this metal concentration in the $0.1 \%$ water extract of AMP was $<0.05 \mu \mathrm{g} / \mathrm{L}$. The experimental model used allowed to estimate the impact of AMP on the body turnover of $\mathrm{Cd}$ at very low (control group vs. AMP group), low ( $\mathrm{Cd}^{1}$ group vs. $\mathrm{Cd}^{1+} \mathrm{AMP}$ group), and moderate ( $\mathrm{Cd}^{5}$ group vs. $\mathrm{Cd}^{5+} \mathrm{AMP}$ group) chronic exposure to $\mathrm{Cd}$. Exposed rats to $1 \mathrm{mg} \mathrm{Cd} / \mathrm{kg}$ of fodder are equivalent to low environmental exposure of humans to this metal, while administering $5 \mathrm{mg} \mathrm{Cd} / \mathrm{kg}$ of fodder is equivalent to moderate exposure of humans.

During the whole experiment, the animals were housed under controlled conventional conditions (temperature 22 $\pm 2^{\circ} \mathrm{C}$, relative humidity $50 \pm 10 \%, 12 / 12 \mathrm{~h}$ light-dark cycle). Animals had free access to drinking water and food during the whole experiment. In the last week of the $3^{\text {rd }}, 10^{\text {th }}$ month of the experiment 8 rats of each group, and all survived animals (8 rats of the control, $\mathrm{Cd}^{1+} \mathrm{AMP}$, and $\mathrm{Cd}^{5+} \mathrm{AMP}$ groups, and 7 rats of the AMP, $\mathrm{Cd}^{1}$, and $\mathrm{Cd}^{5}$ groups) in the last week of the $24^{\text {th }}$ month were placed in metabolic cages for 24-hour urine and faeces collection for five consecutive days. During this time, the animals had free access to food and drinking water (with or without Cd and AMP depending on the experimental group); consumption of which was monitored. The urine and faeces were removed from the metabolic cages every $24 \mathrm{~h}$. The urine was centrifuged (MPW-350R centrifugator, Medical Instruments, Warsaw, Poland) immediately after collection and its volume was measured. The 24-hour urine and faeces collected during the 5-day period were pooled for further analysis.

After the finish treatment, the animals were deprived of food overnight and next they were subjected to barbiturate anaesthesia (Morbital, $30 \mathrm{mg} / \mathrm{kg}$ b.wt, i.p.). The salivary parotid glands were rinsed thoroughly in ice-cold $0.9 \% \mathrm{NaCl}$ (physiological saline). Next, they were weighed with an auto- matic balance $\left(\mathrm{OHAUS}^{\circledR}\right.$. Nanikon, Switzerland; accuracy to $0.0001 \mathrm{gg}$ ). The biological material not used immediately was stored frozen at $-80^{\circ} \mathrm{C}$ until assayed.

The experimental model was described in detail by Brzóska et al. [21].

3.3. Analytical Procedures. The parotid glands were homogenized using a knife homogenizer (Ultra-Turrax T25, IKA) in cold phosphate buffer $(50 \mathrm{mM}, \mathrm{pH}=7.4)$ to obtain $10 \%$ homogenates. Each homogenate was divided into two parts-one portion was centrifuged (MPW-350R, Medical Instruments) $700 \times \mathrm{g}$ for 20 minutes (to determine catalase (CAT), myeloperoxidase (MPO), total antioxidant status (TAS), total oxidant status (TOS), glutathione (GSH), hydrogen peroxide $\left(\mathrm{H}_{2} \mathrm{O}_{2}\right)$, lipid peroxidation (LPO), and protein carbonyl groups (PC)). The other portion was centrifuged $20,000 \times \mathrm{g}$ for 30 minutes (to determine glutathione peroxidase (GPx) and superoxide dismutase (SOD)) at $4^{\circ} \mathrm{C}[43]$.

TAS and TOS were determined using diagnostic kits ImAnOx (TAS) Kit and PerOx (TOS) Kit, Immundiagnostik AG. The TAS values determined in control samples (CTRL1-211.5 $\pm 16.1 \mu \mathrm{mol} / \mathrm{dm}^{3}$ and CTRL2-246 \pm $8.485 \mu \mathrm{mol} / \mathrm{dm}^{3}$ ) confirmed accurateness of the measurements. The precision of the method expressed as coefficient of variation $(\mathrm{CV})$ was $<5 \%$. The TOS values measured in control samples (CTRL1-193.3 $\pm 13.1 \mu \mathrm{mol} / \mathrm{dm}^{3}$ and CTRL2-441.6 $\pm 18.45 \mu \mathrm{mol} / \mathrm{dm}^{3}$ ) were within the ranges provided by the producer. The method precision expressed as coefficient of variation $(\mathrm{CV})$ was $<5.4 \%$. The stress index (OSI) was mathematically calculated as the TOS/TAS ratio.

The activity of CAT was determined by the spectrophometric method according to Aebi [44]. The method precision expressed as coefficient of variation (CV) was $<6 \%$.

The activity of GPx (BIOXYTECH GPx-340 ${ }^{\mathrm{TM}}$ Assay), level of $\mathrm{H}_{2} \mathrm{O}_{2}$ (BIOXYTECH $\mathrm{H}_{2} \mathrm{O}_{2}-560^{\mathrm{TM}}$ Assay), and level of LPO (BIOXYTECH LPO-586 ${ }^{\mathrm{TM}}$ Assay) were determined using diagnostic kits of Percipio Biosciences. The method precision expressed as coefficient of variation $(\mathrm{CV})$ was $<2.2 \%,<4.5 \%$, and $<5 \%$, respectively.

The activity of SOD (Superoxide Dismutase Assay Kit) and the level of GSH (Glutathione Assay Kit) were measured using diagnostic kits of Cayman. The method precision expressed as coefficient of variation $(\mathrm{CV})$ was $<2.5 \%$ and $<4.5 \%$, respectively.

The activity of MPO (Rat MPO ELISA Kit) was determined by a diagnostic kit of SunRed. The method precision expressed as coefficient of variation $(\mathrm{CV})$ was $<5 \%$.

The level of PC was determined by the spectrophotometric method according to Reznick and Packer [45]. The method precision expressed as coefficient of variation (CV) was $<5.6 \%$.

In order to express the parameters on protein basis, total protein concentration was assessed using a diagnostic kit of BioMaxima, where method precision was expressed as coefficient of variation $(\mathrm{CV}<4.8 \%)$.

The level of cadmium in the salivary glands was determined using the atomic absorption spectroscopy (AAS) in graphite cuvette. The level of Cd measured in the 
simultaneously analyzed reference material was consistent with the value provided by the producer (Bovine muscle, ERM-BB184, Belgium). The method precision expressed as coefficient of variation $(\mathrm{CV})$ was $<2 \%$.

All the abovementioned tests were conducted according to the producers' instructions. The measurements were performed using the spectrometer UV VIS SPECORD 50 PLUS (Analytik Jena, Jena, Germany), Epoch microplate reader (BioTek Instruments, Inc.; Winooski, USA), and an automatic washer for Wellwash 4 microplates (Thermo LabSystems, Helsinki, Finland). The level of cadmium was determined using the atomic absorption spectrophotometer (HITACHI Z-5000, Japonia) equipped with a graphite cuvette (Pyro cuvette A, Hitachi) and a hollow cathode lamp for metal determination with the AAS method (Photron, Narre Warren, Australia).

3.4. Statistical Analysis. Statistical analysis of the study results was conducted using the computer program Statistica 13 (StatSoft; Tulsa, USA). The results were presented as mean $\pm \mathrm{SD}$ for 8 rats in each of the experimental groups. In order to assess the statistical variability of differences between the experimental groups, a nonparametric Kruskal-Wallis test was performed. The independent and interactive impact of cadmium and the extract of polyphenol compounds derived from black chokeberries on the indicators of the oxidoreductive status were evaluated using the two-way analysis of variance (ANOVA/MANOVA). The analysis of Spearman's coefficient of correlation was also carried out between $\mathrm{Cd}$ and the indicators of the oxidoreductive status. Differences between the groups were considered statistically significant at $p<0.05$.

\section{Results}

4.1. Indicators of the Antioxidant Status in Parotid Gland Tissue. The values of the indicators of the antioxidant status of the rat parotid gland are presented in Table 1 . The administration of $\mathrm{AE}$ to the study animals for 3 and 10 months had no impact on the activities of CAT, SOD, or GPx and the levels of GSH and TAS in the salivary gland examined. The use of 1 and $5 \mathrm{mg} \mathrm{Cd} / \mathrm{kg}$ of feed for 3 months reduced the activity of CAT compared to the control and did not affect the activity of SOD and GPx and the level of TAS. Prolongation of exposure to 10 months ( 1 and $5 \mathrm{mg} \mathrm{Cd} / \mathrm{kg}$ feed) resulted in reduced GPx and SOD activity. TAS concentration was only lower at the $1 \mathrm{mg} \mathrm{Cd} / \mathrm{kg}$ dose. No changes were found in the activity of CAT in comparison with the control. Moreover, after the two periods ( 3 and 10 months) and levels ( 1 and $5 \mathrm{mg} \mathrm{Cd} / \mathrm{kg}$ feed) of $\mathrm{Cd}$ exposure, no changes were observed in the level of the nonenzymatic antioxidant GSH compared to the control group.

The administration of AE during exposure to $1 \mathrm{mg} \mathrm{Cd} / \mathrm{kg}$ feed for 3 months led to an increase in the activities of CAT and SOD as compared to the group receiving only $\mathrm{Cd}^{1}$. In the $\mathrm{Cd}^{5+} \mathrm{AE}$ group of animals, an increase in TAS concentration was found relative to the control group. In addition, GPx activity was higher than in the group receiving $\mathrm{Cd}^{5}$ only. The prolongation of the exposure to 10 months in the $\mathrm{Cd}^{1+} \mathrm{AE}$ group resulted in an increase in the activity of CAT as compared to the control rats and receiving only $\mathrm{Cd}^{1}$. However, the activities of SOD and GPx were higher in rats exposed to $\mathrm{Cd}^{1}$ alone. The administration of $\mathrm{AE}$ in the case of higher level of exposure to cadmium $\left(\mathrm{Cd}^{5+} \mathrm{AE}\right)$ increased the activities of CAT and GPx concentration as well as TAS as compared to control animals and those exposed only to $5 \mathrm{mg}$ $\mathrm{Cd} / \mathrm{kg}$ feed. It also caused a rise in the activity of SOD as compared to the rats receiving $5 \mathrm{mg} \mathrm{Cd} / \mathrm{kg}$ feed only. In addition, administration of $\mathrm{AE}$ rats for 3 and 10 months when exposed to 1 and $5 \mathrm{mg} \mathrm{Cd} / \mathrm{kg}$ feed did not affect GSH concentration.

The ANOVA/MANOVA analysis (Table 2) suggests that the improvement in the antioxidant status of the submandibular gland of rats receiving $\mathrm{AE}$ during exposure to cadmium ( 1 and $5 \mathrm{mg} \mathrm{Cd} / \mathrm{kg}$ feed) was due to the extract action and interactions of its components with $\mathrm{Cd}$.

4.2. Indicators of the Oxidant Status in Parotid Gland Tissue. The values of the indicators of the oxidant status of the rat parotid gland are presented in Table 3. The administration of $\mathrm{AE}$ to the animals for 3 and 10 months had no effect on the levels of $\mathrm{MPO}, \mathrm{H}_{2} \mathrm{O}_{2}$, LPO, PC, TOS, and stress indicator OSI. In rats exposed to cadmium ( 1 and $5 \mathrm{mg} \mathrm{Cd} / \mathrm{kg}$ feed) for 3 months, the concentration of $\mathrm{PC}$ and $\mathrm{H}_{2} \mathrm{O}_{2}$ increased, while the concentration of TOS and LPO increased at a higher level of exposure (5 mg Cd/kg of feed), as compared to control animals. Prolongation of the exposure to 10 months resulted in an increase in the levels of PC, TOS, and OSI at the exposure to 1 and $5 \mathrm{mg} \mathrm{Cd} / \mathrm{kg}$ feed as compared to control animals. With the higher exposure, a rise was also observed in the levels of $\mathrm{H}_{2} \mathrm{O}_{2}$ and LPO in comparison with control. The application of $\mathrm{AE}$ during exposure to $1 \mathrm{mg} \mathrm{Cd} / \mathrm{kg}$ feed for 3 months caused a decrease in TOS, OSI, $\mathrm{H}_{2} \mathrm{O}_{2}$, and $\mathrm{PC}$ as compared to group of animals receiving only $\mathrm{Cd}^{1}$. When the exposure was higher $\left(\mathrm{Cd}^{5+} \mathrm{AE}\right)$, the levels of LPO and TOS as well as OSI were lower than in the group of animals exposed to $\mathrm{Cd}^{5}$ alone and did not differ from the control. In addition, administration of $\mathrm{AE}$ to animals during exposure to $1 \mathrm{mg} \mathrm{Cd} / \mathrm{kg}$ feed did not affect MPO and LPO levels. The prolongation of the exposure to 10 months resulted in a decrease in OSI, MPO, and PC in the group receiving $\mathrm{Cd}^{1+}$ $\mathrm{AE}$ as compared to the levels observed in rats exposed to $\mathrm{Cd}^{1}$ only and did not differ from the control. With the higher exposure to cadmium ( $\left.\mathrm{Cd}^{5+} \mathrm{AE}\right)$, a decrease was noted in TOS, OSI, and PC as compared to the group given $\mathrm{Cd}^{5}$ alone and did not differ from control rats. In addition, administration of $\mathrm{AE}$ to animals during exposure to $5 \mathrm{mg} \mathrm{Cd} / \mathrm{kg}$ feed did not affect the concentration of MPO, LPO, and $\mathrm{H}_{2} \mathrm{O}_{2}$ in the salivary gland tested.

The ANOVA/MANOVA analysis (Table 4) indicates that the reduction in the oxidant status of the parotid gland of rats receiving $\mathrm{AE}$ during exposure to cadmium (1 and $5 \mathrm{mg} \mathrm{Cd} / \mathrm{kg}$ feed) was due both to the independent effect of the extract and the interactions of its components with $\mathrm{Cd}$. However, the independent effect of AE seems to be stronger.

4.3. Cadmium Concentration. Cd levels in the rat parotid gland are presented in Table 5. 
TABLE 1: Indicators of the antioxidant status of the parotid gland in rats.

\begin{tabular}{|c|c|c|c|c|c|}
\hline & TAS nmol/mg protein & $\begin{array}{c}\text { CAT mmol } \\
\mathrm{H}_{2} \mathrm{O}_{2} / \mathrm{min} / \mathrm{mg} \text { protein }\end{array}$ & $\mathrm{SOD} \mathrm{U} / \mathrm{mg}$ protein & GPx mU/mg protein & $\mathrm{GSH} \mathrm{nmol} / \mathrm{mg}$ protein \\
\hline \multicolumn{6}{|c|}{3 months } \\
\hline Control & $222.4 \pm 18.89$ & $20.45 \pm 2.173$ & $0.526 \pm 0.048$ & $124.2 \pm 13.40$ & $3.160 \pm 0.497$ \\
\hline $\mathrm{AE}$ & $218.0 \pm 13.64$ & $19.46 \pm 2.063$ & $0.480 \pm 0.043$ & $122.0 \pm 11.12$ & $5.088 \pm 0.920$ \\
\hline $\mathrm{Cd}^{1}$ & $208.9 \pm 15.36$ & $6.980 \pm 0.426^{\mathrm{a}, \ddagger, \mathrm{b}, \ddagger}$ & $0.406 \pm 0.029$ & $75.17 \pm 9.086$ & $4.226 \pm 0.710$ \\
\hline $\mathrm{Cd}_{1}+\mathrm{AE}$ & $258.2 \pm 19.24$ & $16.48 \pm 1.104^{\mathrm{c}, \dagger}$ & $0.676 \pm 0.059^{c, \dagger}$ & $105.4 \pm 8.003$ & $4.405 \pm 0.516$ \\
\hline $\mathrm{Cd}^{5}$ & $254.9 \pm 10.77$ & $9.790 \pm 0.980^{\mathrm{a}, *, \mathrm{~b}, *}$ & $0.556 \pm 0.068$ & $88.90 \pm 6.468$ & $2.858 \pm 0.821$ \\
\hline $\mathrm{Cd}_{5}+\mathrm{AE}$ & $296.4 \pm 28.30^{\mathrm{a}, *, \mathrm{~b}, *, \mathrm{c}, *}$ & $14.05 \pm 1.130^{\mathrm{a}, \uparrow}$ & $0.602 \pm 0.049$ & $186.6 \pm 9.204^{\mathrm{c}, \ddagger, \mathrm{d}, *, e, \ddagger}$ & $5.477 \pm 0.655$ \\
\hline \multicolumn{6}{|c|}{10 months } \\
\hline Control & $184.8 \pm 7.274$ & $14.68 \pm 1.301$ & $0.583 \pm 0.070$ & $80.96 \pm 5.248$ & $3.311 \pm 0.750$ \\
\hline $\mathrm{AE}$ & $185.1 \pm 26.85$ & $14.61 \pm 1.415$ & $0.512 \pm 0.114$ & $100.4 \pm 15.53$ & $2.853 \pm 0.648$ \\
\hline $\mathrm{Cd}^{1}$ & $124.0 \pm 9.215^{\mathrm{a}, *}$ & $12.07 \pm 0.854$ & $0.161 \pm 0.020^{\mathrm{a}, \sharp, \mathrm{b}, *}$ & $48.20 \pm 5.031^{\mathrm{a}, *}$ & $2.822 \pm 0.400$ \\
\hline $\mathrm{Cd}_{1}+\mathrm{AE}$ & $200.5 \pm 15.38^{\mathrm{c}, *}$ & $30.76 \pm 3.087^{\mathrm{a}, *, \mathrm{~b}, *, \mathrm{c}, \neq}$ & $0.449 \pm 0.062^{\mathrm{c}, \dagger}$ & $108.0 \pm 11.43^{\mathrm{c}, \dagger}$ & $3.242 \pm 0.462$ \\
\hline $\mathrm{Cd}^{5}$ & $155.1 \pm 7.972$ & $11.93 \pm 1.087^{\mathrm{d}, \sharp}$ & $0.255 \pm 0.025^{\mathrm{a}, *}$ & $55.32 \pm 5.433^{\mathrm{a}, *, \mathrm{~d}, *}$ & $2.338 \pm 0.330$ \\
\hline $\mathrm{Cd}_{5}+\mathrm{AE}$ & $341.5 \pm 18.63^{\mathrm{a}, *, \mathrm{~b}, *, \mathrm{c}, \sharp, \mathrm{e}, \dagger}$ & $23.92 \pm 2.447^{\mathrm{a}, *, \mathrm{c}, \sharp, e, *}$ & $0.545 \pm 0.076^{\mathrm{c}, \neq, \mathrm{e}, *}$ & $157.3 \pm 21.90^{\mathrm{a}, *, \mathrm{~b}, \sharp, \mathrm{c}, \sharp, \mathrm{e}, \sharp}$ & $5.346 \pm 1.506^{\mathrm{b}}$ \\
\hline
\end{tabular}

Data is mean \pm SD for 8 rats. Statistically significant differences (nonparametric Kruskal-Wallis test). ${ }^{\mathrm{a} C o m p a r e d ~ t o ~ c o n t r o l . ~}{ }^{\mathrm{b}} \mathrm{Compared}$ to AE group. ${ }^{\mathrm{c}}$ Compared to $\mathrm{Cd}^{1}$ group. ${ }^{\mathrm{d}}$ Compared to $\mathrm{Cd}^{1+} \mathrm{AE}$ group. ${ }^{\mathrm{e}}$ Compared to $\mathrm{Cd}^{5}$ group; ${ }^{*} p<0.05,{ }^{\dagger} p<0.01,{ }^{\ddagger} p<0.001$, respectively.

TABLE 2: Estimation of the main and interactive effects of $\mathrm{Cd}$ and $\mathrm{AE}$ on the indicators of the antioxidant status of the parotid gland in rats.

\begin{tabular}{lcccc}
\hline & TAS & CAT & SOD & GPx \\
\hline Main effect of Cd & $3.906^{\mathrm{a}}$ & NS & NS & NS \\
Main effect of AE & $9.741^{\dagger}$ & $15.12^{\ddagger}$ & NS & $23.09^{\ddagger}$ \\
Interactive effect of Cd and AE & $10.67^{\dagger}$ & $18.30^{\ddagger}$ & $11.33^{\dagger}$ & $14.30^{\ddagger}$ \\
\hline
\end{tabular}

Data present $F$ values and level of statistical significance. ${ }^{\dagger} p<0.01$, ${ }^{*} p<0.001,{ }^{\mathrm{a}} p=0.05$, NS $p>0.05$.

In the rats exposed to 1 and $5 \mathrm{mg} \mathrm{Cd} / \mathrm{kg}$ feed, for 3 and 10 months, the level of this metal in the parotid gland was higher than in the control. The administration of AE during cadmium exposure $\left(\mathrm{Cd}^{1+} \mathrm{AE}\right.$ and $\left.\mathrm{Cd}^{5+} \mathrm{AE}\right)$ resulted in reduced accumulation of this metal in the gland as compared to the animals receiving $\mathrm{Cd}^{1}$ and $\mathrm{Cd}^{5}$ alone. However, the levels of this metal in these groups $\left(\mathrm{Cd}^{1+} \mathrm{AE}\right.$ and $\mathrm{Cd}^{5+}$ $\mathrm{AE}$ ) were higher than in the control group. As shown by the ANOVA/MANOVA variance analysis (Table 6), the level of cadmium in the parotid gland of rats receiving Aronia melanocarpa extract depended on the independent cadmium action.

Numerous correlations were noted between the level of $\mathrm{Cd}$ and the indicators of the oxidoreductive status of the parotid gland studied (Table 7). All the indicators of the oxidation state (TOS, OSI, MPO, PC, $\mathrm{H}_{2} \mathrm{O}_{2}$, LPO) were positively correlated with cadmium exposure. A negative correlation was observed between OSI and the activity of antioxidant enzymes (CAT, SOD, GPx) and TAS. A positive correlation was found between OSI and indicators of the oxidant state (MPO, PC, LPO, $\mathrm{H}_{2} \mathrm{O}_{2}$ ) and TOS.

\section{Discussion}

Oxidative stress exerts an unfavorable effect on the human body and is a major factor in the pathomechanism of many systemic diseases. Its involvement in the etiology of the diseases affecting the circulatory system, nervous system, osseous system, and kidney [20, 24, 25, 46, 47], as well as in the pathogenesis of oral disorders [48-53] has been described.

Experimental studies conducted in recent years allowed researchers to state that oxidative stress is also a mechanism underlying the toxic action of cadmium. The mechanism of stress development in conditions of exposure to cadmium is multidirectional $[20,22-25] . \mathrm{Cd}^{2+}$ ions are not capable to directly generate reactive oxygen species (ROS), but they can lead to, via indirect mechanisms, oxidative injuries in numerous tissues and organs, including the salivary glands. These mechanisms involve disorders in the mitochondrial respiratory chain, attenuation of the protective antioxidant barrier, reduction in the thiol status, and release of transitory metal ions [22, 23].

Increased generation of reactive oxygen species and oxidative damage to macromolecules and cell organelles are due to cadmium-induced attenuation of cell antioxidant potential. ROS, as highly reactive structures, easily come into interactions with proteins, sugars, polyunsaturated fatty acids, and nucleic acids, leading to disorders in their biological functions $[20,22,24,25]$.

The exposure of rats to $1 \mathrm{mg} \mathrm{Cd} / \mathrm{kg}$ feed corresponds to low environmental human exposure to this metal, whereas a dose of $5 \mathrm{mg} \mathrm{Cd} / \mathrm{kg}$ feed reflects moderate exposure. The levels of $\mathrm{Cd}$ in blood and urine of animals exposed to 1 and $5 \mathrm{mg} \mathrm{Cd} / \mathrm{kg}$ feed were in the range of $0.1030-0.3060 \mu \mathrm{g} / \mathrm{dm}^{3}$ 
TABLE 3: Indicators of the oxidant status of the parotid gland in rats.

\begin{tabular}{|c|c|c|c|c|c|c|}
\hline & $\begin{array}{c}\text { TOS } \\
\text { (nmol/mg protein) }\end{array}$ & $\begin{array}{c}\text { OSI } \\
\text { (TOS/TAS) }\end{array}$ & $\begin{array}{c}\text { MPO } \\
\text { (ng/mg protein) }\end{array}$ & $\begin{array}{c}\mathrm{H}_{2} \mathrm{O}_{2} \\
\text { (nmol/mg protein) }\end{array}$ & $\begin{array}{c}\text { LPO } \\
(\mathrm{nmol} / \mathrm{mg} \text { protein })\end{array}$ & $\begin{array}{c}\text { PC } \\
\text { (nmol/mg protein) }\end{array}$ \\
\hline \multicolumn{7}{|c|}{3 months } \\
\hline Control & $24.66 \pm 3.716$ & $0.112 \pm 0.016$ & $6.184 \pm 0.500$ & $6.743 \pm 0.765$ & $1.862 \pm 0.167$ & $26.98 \pm 2.99$ \\
\hline $\mathrm{AE}$ & $22.11 \pm 2.446$ & $0.104 \pm 0.014$ & $4.915 \pm 0.447$ & $6.416 \pm 0.614$ & $1.916 \pm 0.204$ & $19.98 \pm 1.455$ \\
\hline $\mathrm{Cd}^{1}$ & $29.98 \pm 4.387$ & $0.145 \pm 0.021$ & $7.317 \pm 0.665$ & $9.204 \pm 0.642^{\mathrm{a}, *}$ & $2.235 \pm 0.270$ & $40.85 \pm 2.279^{\mathrm{a}, *, \mathrm{~b}, \dagger}$ \\
\hline $\mathrm{Cd}_{1}+\mathrm{AE}$ & $12.22 \pm 1.642^{\mathrm{c}, *}$ & $0.051 \pm 0.009^{\mathrm{c}, \uparrow}$ & $5.136 \pm 0.515$ & $6.371 \pm 0.666^{\mathrm{c}, *}$ & $1.771 \pm 0.144$ & $20.83 \pm 2.357^{\mathcal{c}, *}$ \\
\hline $\mathrm{Cd}^{5}$ & $44.16 \pm 8.377^{\mathrm{a}, *, \mathrm{~b}, *, \mathrm{~d}, \dagger}$ & $0.173 \pm 0.032^{\mathrm{d}, \dagger}$ & $7.444 \pm 0.476$ & $8.835 \pm 0.304^{\mathrm{a}, *}$ & $3.927 \pm 0.915^{\mathrm{a}, *, \mathrm{~b}, *, \mathrm{~d}, *}$ & $45.40 \pm 6.907^{\mathrm{a}, *, \mathrm{~b}, \sharp, \mathrm{d}, \dagger}$ \\
\hline $\mathrm{Cd}_{5}+\mathrm{AE}$ & $18.18 \pm 4.155^{\mathrm{e}, \dagger}$ & $0.064 \pm 0.016^{\mathrm{c}, *, \mathrm{e}, *}$ & $5.803 \pm 0.482$ & $7.446 \pm 0.473$ & $2.098 \pm 0.208^{\mathrm{e}, *}$ & $28.93 \pm 1.719$ \\
\hline \multicolumn{7}{|c|}{10 months } \\
\hline Control & $24.63 \pm 8.303$ & $0.132 \pm 0.040$ & $5.828 \pm 0.586$ & $6.427 \pm 0.332$ & $1.800 \pm 0.306$ & $19.60 \pm 1.660$ \\
\hline $\mathrm{AE}$ & $20.03 \pm 3.535$ & $0.122 \pm 0.025$ & $3.898 \pm 0.372$ & $5.946 \pm 0.481$ & $1.772 \pm 0.253$ & $19.38 \pm 3.165$ \\
\hline $\mathrm{Cd}^{1}$ & $48.37 \pm 8.682^{\mathrm{a}, *, \mathrm{~b}, *}$ & $0.419 \pm 0.095^{\mathrm{a}, *, \mathrm{~b}, *}$ & $7.045 \pm 0.668$ & $7.334 \pm 0.557$ & $2.153 \pm 0.217$ & $38.57 \pm 6.440^{\mathrm{a}, *}$ \\
\hline $\mathrm{Cd}_{1}+\mathrm{AE}$ & $36.13 \pm 6.036$ & $0.188 \pm 0.032^{\mathfrak{c}, *}$ & $3.840 \pm 0.265^{\mathrm{c}, *}$ & $7.232 \pm 0.475$ & $1.664 \pm 0.125$ & $19.68 \pm 3.169^{c, *}$ \\
\hline $\mathrm{Cd}^{5}$ & $69.46 \pm 10.11^{\mathrm{a}, \dagger, \mathrm{b}, \ddagger}$ & $0.464 \pm 0.077^{\mathrm{a}, \dagger, \mathrm{b}, *}$ & $9.192 \pm 1.407$ & $10.52 \pm 1.446^{\mathrm{a}, *, \mathrm{~b}, \dagger}$ & $2.942 \pm 0.285^{\mathrm{a}, *, \mathrm{~d}, *}$ & $45.05 \pm 6.289^{\mathrm{a}, \dagger, \mathrm{b}, \dagger, \mathrm{d}, \uparrow}$ \\
\hline $\mathrm{Cd}_{5}+\mathrm{AE}$ & $42.29 \pm 3.989^{\mathrm{b}, \dagger, \mathrm{e}, *}$ & $0.125 \pm 0.011^{\mathrm{e}, *}$ & $6.496 \pm 0.494$ & $8.837 \pm 0.678^{\mathrm{b}, \uparrow}$ & $2.144 \pm 0.190$ & $34.08 \pm 4.822^{\mathrm{e}, *}$ \\
\hline
\end{tabular}

Data is mean \pm SD for 8 rats. Statistically significant differences (nonparametric Kruskal-Wallis test). ${ }^{\mathrm{a}}$ Compared to control. ${ }^{\mathrm{b}}$ Compared to AE group. ${ }^{\mathrm{c}}$ Compared to $\mathrm{Cd}^{1}$ group. ${ }^{\mathrm{d}}$ Compared to $\mathrm{Cd}^{1+} \mathrm{AE}$ group. ${ }^{\mathrm{e}}$ Compared to $\mathrm{Cd}^{5}$ group; ${ }^{*} p<0.05,{ }^{\dagger} p<0.01,{ }^{\ddagger} p<0.001$, respectively.

TABLE 4: Estimation of the main and interactive effects of $\mathrm{Cd}$ and $\mathrm{AE}$ on the indicators of the oxidation state of the parotid gland in rats.

\begin{tabular}{|c|c|c|c|c|c|c|}
\hline & TOS & OSI & MPO & $\mathrm{H}_{2} \mathrm{O}_{2}$ & LPO & PC \\
\hline Main effect of Cd & $11.85^{\ddagger}$ & $7.539^{\dagger}$ & $10.51^{\dagger}$ & $17.16^{\ddagger}$ & $5.793^{*}$ & $26.77^{\ddagger}$ \\
\hline Main effect of $\mathrm{AE}$ & $8.091^{\dagger}$ & $10.46^{\dagger}$ & $24.19^{\ddagger}$ & $4.700^{*}$ & $4.017^{*}$ & $19.95^{\ddagger}$ \\
\hline Interactive effect of $\mathrm{Cd}$ and $\mathrm{AE}$ & $4.043^{\dagger}$ & $8.656^{\dagger}$ & NS & NS & $4.260^{*}$ & $7.002^{\dagger}$ \\
\hline
\end{tabular}

Data present $F$ values and the level of statistical significance. ${ }^{*} p<0.05,{ }^{\dagger} p<0.01,{ }^{*} p<0.001$, NS $p>0.05$.

TABle 5: The levels of cadmium in the parotid gland.

\begin{tabular}{lcc}
\hline & 3-month exposure & 10-month exposure \\
\hline Cd $\mu \mathrm{g} / \mathrm{g}$ tissue & & \\
Control & $0.0344 \pm 0.0099$ & $0.0950 \pm 0.0024$ \\
$\mathrm{AE}$ & $0.0075 \pm 0.0007$ & $0.0939 \pm 0.0020$ \\
$\mathrm{Cd}^{1}$ & $0.4053 \pm 0.0294^{\mathrm{a}, *, \mathrm{~b}, *}$ & $0.7328 \pm 0.0417^{\mathrm{a}, *, \mathrm{~b}, *}$ \\
$\mathrm{Cd}_{1}+\mathrm{AE}$ & $0.2442 \pm 0.0300^{\mathrm{a}, *, \mathrm{c}, *}$ & $0.5876 \pm 0.0318^{\mathrm{a} * \mathrm{c} *}$ \\
$\mathrm{Cd}^{5}$ & $1.4871 \pm 0.0294^{\mathrm{a}, \sharp, \mathrm{b}, \sharp, \mathrm{d}, *}$ & $2.0430 \pm 0.0913^{\mathrm{a}, \sharp, \mathrm{b}, \ddagger, \mathrm{d}, *}$ \\
$\mathrm{Cd}_{5}+\mathrm{AE}$ & $1.0370 \pm 0.0982^{\mathrm{a}, \uparrow, \mathrm{b}, \sharp, \mathrm{e}, *}$ & $1.7370 \pm 0.0578^{\mathrm{a}, \ddagger, \mathrm{b}, \ddagger, \mathrm{e}, *}$ \\
\hline
\end{tabular}

Data is mean \pm SD for 8 rats. Statistically significant differences (nonparametric Kruskal-Wallis test). ${ }^{\mathrm{a} C o m p a r e d ~ t o ~ c o n t r o l . ~}{ }^{\mathrm{b}}$ Compared to $\mathrm{AE}$ group. ${ }^{\mathrm{c}}$ Compared to $\mathrm{Cd}^{1}$ group. ${ }^{\mathrm{d}}$ Compared to $\mathrm{Cd}^{1+} \mathrm{AE}$ group. ${ }^{\mathrm{e}}$ Compared to $\mathrm{Cd}^{5}$ group; ${ }^{*} p<0.05,{ }^{\dagger} p<0.01,{ }^{*} p<0.001$, respectively.

and $0.0852-0.2762 \mu \mathrm{g} / \mathrm{g}$ creatinine and $0.5840-1.3320$ $\mu \mathrm{g} / \mathrm{dm}^{3}$ and $0.2839-0.8197 \mu \mathrm{g} / \mathrm{g}$ creatinine [21]. The same ranges of Cd levels can be observed in the residents of highly industrialized countries, which may indicate that the experimental model applied well reflects the environmental exposure of the general population to this metal. The ranges of $\mathrm{Cd}$ levels noted in rats exposed to $5 \mathrm{mg} \mathrm{Cd} / \mathrm{kg}$ feed or even much higher are observed in heavy smokers.
TABLE 6: Estimation of the main and interactive effects of $\mathrm{Cd}$ and $\mathrm{AE}$ on the parotid gland.

\begin{tabular}{cccc}
\hline & $\begin{array}{c}\text { Main effect of } \\
\text { Cd }\end{array}$ & $\begin{array}{c}\text { Main effect of } \\
\text { AE }\end{array}$ & $\begin{array}{c}\text { Interactive effect of Cd and } \\
\text { AE }\end{array}$ \\
\hline Cd & $\mathbf{7 6 . 0 0}^{\ddagger}$ & NS & NS
\end{tabular}

Data present $F$ values and level of statistical significance. ${ }^{*} p<0.001$, NS $p>0.05$.

We found that cadmium leads to the development of oxidative stress in the parotid gland by damaging the enzymatic antioxidant barrier. We observed that the administration of 1 and $5 \mathrm{mg} \mathrm{Cd} / \mathrm{kg}$ feed to rats for 3 months caused a reduction in the activity of CAT by $66 \%$ and $52 \%$, respectively. No changes were noted in the activity of SOD, GPx, and the level of TAS. The prolongation of the exposure to 10 months (1 and $5 \mathrm{mg} \mathrm{Cd} / \mathrm{kg}$ feed) resulted in a decrease in the activity of SOD by $72 \%$ and $56 \%$ and GPx by $40 \%$ and $32 \%$. TAS concentration was only lower in rats receiving $1 \mathrm{mg} \mathrm{Cd} / \mathrm{kg}$ feed by $33 \%$. No changes, however, were found in the activity of CAT, what may be induced by organism adaptation to long Cd exposure. Moreover, after both periods ( 3 and 10 months) and levels ( 1 and $5 \mathrm{mg} \mathrm{Cd} / \mathrm{kg}$ feed) of exposure to cadmium, 
TABLE 7: Analysis of the correlation between the study parameters of the oxidoreductive status of the parotid gland and cadmium concentration.

\begin{tabular}{|c|c|c|c|c|c|c|c|c|c|c|c|}
\hline & $\mathrm{Cd}$ & TOS & TAS & OSI & CAT & SOD & GPx & GSH & $\mathrm{MPO}$ & PC & $\mathrm{H}_{2} \mathrm{O}_{2}$ \\
\hline$\overline{\text { TOS }}$ & $0.482^{\ddagger}$ & & & & & & & & & & \\
\hline TAS & NS & NS & & & & & & & & & \\
\hline OSI & $0.356^{\ddagger}$ & $0.908^{*}$ & $-0.496^{\ddagger}$ & & & & & & & & \\
\hline CAT & NS & NS & $0.290^{\ddagger}$ & $-0.212^{*}$ & & & & & & & \\
\hline SOD & $-0.216^{*}$ & $-0.395^{\ddagger}$ & $0.614^{\ddagger}$ & $-0.585^{\ddagger}$ & $0.277^{\dagger}$ & & & & & & \\
\hline GPx & NS & $-0.215^{*}$ & $0.610^{\ddagger}$ & $-0.418^{\ddagger}$ & $0.467^{\ddagger}$ & $0.499^{\ddagger}$ & & & & & \\
\hline GSH & NS & NS & $0.346^{\ddagger}$ & NS & $0.210^{*}$ & $0.204^{*}$ & $0.392^{\ddagger}$ & & & & \\
\hline MPO & $0.371^{\ddagger}$ & $0.348^{\ddagger}$ & NS & $0.250^{*}$ & $-0.378^{\ddagger}$ & NS & $-0.263^{\dagger}$ & NS & & & \\
\hline PC & $0.575^{\ddagger}$ & $0.445^{\ddagger}$ & NS & $0.305^{\dagger}$ & $-0.285^{\dagger}$ & NS & NS & NS & $0.504^{\ddagger}$ & & \\
\hline $\mathrm{H}_{2} \mathrm{O}_{2}$ & $0.534^{\ddagger}$ & $0.396^{\ddagger}$ & $0.273^{\dagger}$ & $0.259^{*}$ & NS & NS & NS & NS & $0.325^{\dagger}$ & $0.766^{\ddagger}$ & \\
\hline LPO & $0.390^{\ddagger}$ & $0.356^{\ddagger}$ & $0.249^{*}$ & $0.214^{*}$ & NS & NS & NS & NS & $0.349^{*}$ & $0.742^{*}$ & $0.665^{\ddagger}$ \\
\hline
\end{tabular}

${ }^{*} p<0.05,{ }^{\dagger} p<0.01,{ }^{*} p<0.001, \mathrm{NS} p>0.05$.

no changes were revealed in the level of the nonenzymatic antioxidant GSH.

In the current study, in rats exposed to cadmium in both concentrations ( 1 and $5 \mathrm{mg} \mathrm{Cd} / \mathrm{kg}$ feed), the level of PC was increased by $51 \%$ and $68 \%$, respectively, and $\mathrm{H}_{2} \mathrm{O}_{2}$ by $36 \%$ and $31 \%$, respectively, and TOS and LPO at the higher level of exposure ( $5 \mathrm{mg} \mathrm{Cd} / \mathrm{kg}$ feed) by $79 \%$ and 2.1 -fold, respectively, as compared to control animals after 3 months of exposure. The prolongation of the exposure to 10 months resulted in an increase in the levels of PC, TOS, and OSI by $97 \%, 2$ - and 3.2-fold, respectively, at the exposure to $1 \mathrm{mg}$ $\mathrm{Cd} / \mathrm{kg}$ feed and 2.3-fold, 2.8-fold, and 3.5-fold, respectively, at the exposure to $5 \mathrm{mg} \mathrm{Cd} / \mathrm{kg}$ feed as compared to control animals. At the higher level of the exposure, an increase was also noted in the level of $\mathrm{H}_{2} \mathrm{O}_{2}$ (by 64\%) and LPO (by $63 \%$ ) in comparison with the control group.

The oxidative damage observed in our research to proteins and lipids with a simultaneous increase in $\mathrm{H}_{2} \mathrm{O}_{2}$ and the inhibition of the activity of antioxidant enzymes in rat parotid gland tissue seem to indicate the development of oxidative stress in this gland. This reasoning is confirmed by the finding of oxidative/antioxidative imbalance in the tissue examined, which was reflected in the increased TOS/TAS ratio being a stress marker (OSI) in the parotid gland already after the 3-month exposure to $5 \mathrm{mg} \mathrm{Cd} / \mathrm{kg}$ feed and after the 10 -month exposure to 1 and $5 \mathrm{mg} \mathrm{Cd} / \mathrm{kg}$ feed.

Importantly, we found that the consumption of black chokeberry fruit extract during exposure to cadmium can protect, at least partly, against disorders in the enzymatic and nonenzymatic antioxidant barrier and prevent oxidative damage to cell macromolecules in parotid gland tissue.

The administration of $\mathrm{AE}$ to animals during exposure to $1 \mathrm{mg} \mathrm{Cd} / \mathrm{kg}$ feed for 3 months increased the activity of CAT (2.4-fold) and SOD (by 66\%) as compared to the group receiving $\mathrm{Cd}^{1}$ only. In the $\mathrm{Cd}^{5+} \mathrm{AE}$ group, an increase was found in the activity of TAS (by 33\%) compared to the control group. Moreover, the activity of GPx was higher (2.1-fold) than in the $\mathrm{Cd}^{5}$ group. The prolongation of the exposure to 10 months in the $\mathrm{Cd}^{1+} \mathrm{AE}$ group resulted in the increased activity of CAT in comparison with control rats and those receiving $\mathrm{Cd}^{1}$ only, 2.1-fold and 2.5-fold, respectively. However, the activities of SOD and GPx concentration were higher than in the rat group exposed to $\mathrm{Cd}^{1}$ only 2.8 - and 2.2 -fold, respectively. The administration of $\mathrm{AE}$ at the higher level of exposure to cadmium $\left(\mathrm{Cd}^{5+} \mathrm{AE}\right)$ caused an increase in the activity of CAT (by $63 \%$ and 2 -fold, respectively), GPx (by $94 \%$ and 2.8 fold), and TAS (by $85 \%$ and 2.2 -fold, respectively) as compared to control animals and rats exposed only to $5 \mathrm{mg}$ $\mathrm{Cd} / \mathrm{kg}$ feed. It also brought an increase in the activity of SOD in comparison with rats receiving only $5 \mathrm{mg} \mathrm{Cd} / \mathrm{kg}$ feed by $92 \%$. Importantly, the administration of A. melanocarpa fruit extract during exposure to $5 \mathrm{mg} \mathrm{Cd} / \mathrm{kg}$ feed already after 3 months completely prevented cadmiuminduced reduction in the activity of GPx and even increased TAS as compared to the control. However, the administration of $\mathrm{AE}$ during exposure to 1 or $5 \mathrm{mg} \mathrm{Cd} / \mathrm{kg}$ feed for 10 months fully protected the activities of CAT, SOD i GPx, and TAS concentration against reduction and even at a higher level of exposure increased the activities of CAT, GPx, and TAS concentration compared to the control. As shown by the analysis of variance ANOVA/MANOVA, the beneficial effect of the extract administration was associated with its independent action and with interactions of its components with $\mathrm{Cd}$. Taking into account the results of this analysis and the fact that A. melanocarpa fruit extract is characterized by strong antioxidant properties $[35,37,54-60]$, and that its administration during cadmium exposure increased the antioxidant potential of the parotid gland, it can be assumed that the beneficial effect of the extract on the activity of the enzymes and the levels of GSH and TAS was due to its antioxidant effect.

The administration of AE to animals during exposure to $1 \mathrm{mg} \mathrm{Cd} / \mathrm{kg}$ feed for 3 months resulted in lower values of TOS (by $59 \%$ ), OSI (by $65 \%$ ), $\mathrm{H}_{2} \mathrm{O}_{2}$ (by $31 \%$ ), and $\mathrm{PC}$ (by $49 \%$ ) than in the group of rats receiving $\mathrm{Cd}^{1}$ only. At the higher level of exposure $\left(\mathrm{Cd}^{5+} \mathrm{AE}\right)$, the concentrations of $\mathrm{LPO}$, TOS, and OSI values were lower than in the group of animals 
exposed only to $\mathrm{Cd}^{5}$ by $47 \%, 59 \%$, and $63 \%$, respectively, and did not differ from the control group. The prolongation of the exposure to 10 months caused a reduction in OSI (by $55 \%$ ), MPO (by $34 \%$ ), and PC (by $49 \%$ ) in the $\mathrm{Cd}^{1+} \mathrm{AE}$ group as compared to rats exposed to the metal alone $\left(\mathrm{Cd}^{1}\right)$ and did not differ from the control. At the higher level of exposure to cadmium $\left(\mathrm{Cd}^{5+} \mathrm{AE}\right)$, TOS, OSI, and PC were reduced by $39 \%, 73 \%$, and $24 \%$, respectively, in comparison with the animals receiving only $\mathrm{Cd}^{5}$. An important finding was that the administration of A. melanocarpa fruit extract during exposure for 3 months to cadmium can protect against the increase in the levels of TOS and OSI at both levels of exposure to this metal, $\mathrm{H}_{2} \mathrm{O}_{2}$ and $\mathrm{PC}$ at $1 \mathrm{mg} \mathrm{Cd} / \mathrm{mg}$ feed, and $\mathrm{LPO}$ at $5 \mathrm{mg} \mathrm{Cd} / \mathrm{mg}$ feed. In turn, the 10-month administration of $\mathrm{AE}$ in animals exposed to 1 and $5 \mathrm{mg} \mathrm{Cd} / \mathrm{mg}$ feed completely prevented the Cd-induced increase in OSI and PC, MPO concentration at $1 \mathrm{mg} \mathrm{Cd} / \mathrm{mg}$ feed, and in TOS at $5 \mathrm{mg} \mathrm{Cd} / \mathrm{mg}$ feed. The two-way analysis of variance ANOVA/MANOVA showed that the beneficial effect of A. melanocarpa fruit extract on the indicators of the oxidative status of the parotid gland is due to an independent action of the extract as well as interactions of its components with cadmium. Importantly, the relatively high content of polyphenol compounds in black chokeberry fruit [35-37, 56, 57] and their ability to chelate toxic heavy metal ions [39] allow the assumption that these compounds play a major role in the prevention of oxidative damage to cell macromolecules (PC, LPO) and of an increase in the levels of $\mathrm{H}_{2} \mathrm{O}_{2}, \mathrm{MPO}$, TOS, and OSI in the parotid gland.

In the light of the available data, the independent protective impact of black chokeberry fruit extract on the enzymatic and nonenzymatic antioxidant barrier, indicators of the oxidant status, and the degree of damage to oxidant cell macromolecules in the parotid gland can be explained by high antioxidant potential of this extract determined mainly by polyphenol compounds $[35,37,56,57]$. Our earlier research conducted using the same experimental model as the one applied in the current study revealed that the administration of black chokeberry fruit extract to rats chronically exposed to cadmium enhances the enzymatic and nonenzymatic antioxidant barrier, protects from excessive accumulation of $\mathrm{H}_{2} \mathrm{O}_{2}$, reduces the level of PC, LPO, and MPO, and decreases TOS and OSI in bone tissue [26] and liver [29,30].

The interactive effect of A. melanocarpa fruit extract and cadmium on the oxidoreductive status in the parotid gland can be justified by the ability of the extract component, especially polyphenol compounds $[34,39,59]$, as well as fiber, tannins, and pectin $[35,57,58]$ to bind divalent metal ions. The presence of a large number of hydroxyl groups in the molecule enables these compounds to form complexes with metal ions $[35-37,56,57]$ and facilitates chelation of toxic metal ions, including cadmium, as well as metals that catalyze oxidation reactions, such as copper(I) and iron(II) $[39,60]$. It is thus assumed that the polyphenol compounds present in A. melanocarpa fruit can be responsible for $\mathrm{Cd}^{2+}$ uptake in the lumen of the alimentary tract and in this way reduce its absorption and bioavailability $[21,59]$. We found that both the low and moderate exposures to cadmium from 3 to 10 months increased its level in the gland examined, whereas administration of $0.1 \%$ extract of A. melanocarpa fruit during exposure to this xenobiotic decreased its accumulation in the parotid gland. This allows the suggestion that the beneficial effect of the extract consumption was, at least partly, caused by diminished absorption and accumulation of cadmium in the body and in consequence prevented negative health effects caused by this toxic metal, including its prooxidant action. Moreover, numerous correlations between cadmium and indicators of the oxidant/antioxidant status in animals simultaneously receiving A. melanocarpa extract and cadmium in the diet seem to confirm the contribution of the antioxidant properties of the extract in the mechanism of its protective impact on the parotid gland.

The current report is one of the first to assess the effect of A. melanocarpa fruit extract on the oxidoreductive balance in the parotid gland in conditions of low and moderate exposures to $\mathrm{Cd}$. However, some experimental studies have proved that such polyphenol compounds as curcumin and resveratrol show a protective action against oxidative stress, but not cadmium-induced, in the salivary glands $[60,61]$.

In summary, it should be stated that even low exposure to cadmium may lead to enzymatic disorders (reduced activity of CAT, SOD, GPx) of the antioxidant barrier, cause oxidative disorders of important cell macromolecules (increased PC), reduce total antioxidant status TAS, and increase total oxidant state TOS and stress indicator OSI. The consumption of black chokeberry fruit extract during low and moderate exposures to this xenobiotic increases the activity of CAT, SOD, GPx, and TAS and prevents the Cd-induced increase in the levels of PC, LPO, MPO, $\mathrm{H}_{2} \mathrm{O}_{2}$, TOS, and OSI in the parotid gland. Our results seem to confirm the hypothesis that the consumption of black chokeberry products during low and moderate exposures to cadmium in the diet may have a protective effect on the parotid gland and prevent its damage.

\section{Conclusions}

Our study results contribute to the current knowledge of the protective role of Aronia melanocarpa fruit extract on the parotid gland during exposure to cadmium and confirm the benefits of black chokeberry fruit preserves in the prevention of unfavorable effects of this heavy metal on the oral health.

\section{Data Availability}

This is the Data Availability statement for the manuscript titled "The Protective Impact of Black Chokeberry Fruit Extract (Aronia melanocarpa L.) on the Oxidoreductive System of the Parotid Gland of Rats Exposed to Cadmium". The data of the materials and methods and conclusions to support the findings of this study are included within the article. If any other data may be needed, please contact the corresponding author upon request.

\section{Conflicts of Interest}

There is no conflict of interest. There has been no support for the work in the submitted manuscript; financial relationships 
with any entities that could be viewed as relevant to the general area of the submitted manuscript; payments to you or to institution in the 36 months prior to submission; any other interactions with the sponsor of outside of the submitted work should also be reported; any relevant patents or copyrights (planned, pending, or issued); and any other relationships or affiliations that may be perceived by readers to have influenced or give the appearance of potentially influencing in the submitted work.

\section{Acknowledgments}

This work was supported by the Grant (No. N N405 051140) from the Narodowe Centrum Nauki (Poland). The study was conducted with the use of equipment by the Medical University of Bialystok (Poland) as part of the OP DEP 2007-2013, Priority Axis I.3, contract No. POPW.01.00-20-001/12.

\section{References}

[1] S. Satarug, D. A. Vesey, and G. C. Gobe, "Current health risk assessment practice for dietary cadmium: data from different countries," Food and Chemical Toxicology, vol. 106, Part A, pp. 430-445, 2017.

[2] S. Satarug, D. A. Vesey, and G. C. Gobe, "Health risk assessment of dietary cadmium intake: do current guidelines indicate how much is safe?," Environmental Health Perspectives, vol. 125, no. 3, pp. 284-288, 2017.

[3] M. Mężyńska and M. M. Brzóska, "Environmental exposure to cadmium - a risk for health of the general population in industrialized countries and preventive strategies," Environmental Science and Pollution Research, vol. 25, no. 4, pp. 3211-3232, 2018.

[4] S. Mishra, R. N. Bharagava, N. More et al., "Heavy metal contamination: an alarming threat to environment and human health," in Environmental Biotechnology: For Sustainable Future, R. C. Sobti, N. K. Arora, and R. Kothari, Eds., pp. 103-125, Springer, Singapore, 2019.

[5] J. M. Madrigal, A. C. Ricardo, V. Persky, and M. Turyk, "Associations between blood cadmium concentration and kidney function in the U.S. population: impact of sex, diabetes and hypertension," Environmental Research, vol. 169, pp. 180$188,2019$.

[6] D. Wang, H. Sun, Y. Wu et al., "Tubular and glomerular kidney effects in the Chinese general population with low environmental cadmium exposure," Chemosphere, vol. 147, pp. 3-8, 2016.

[7] O. Hyder, M. Chung, D. Cosgrove et al., "Cadmium exposure and liver disease among US adults," Journal of Gastrointestinal Surgery, vol. 17, no. 7, pp. 1265-1273, 2013.

[8] M. Y. Kang, S. H. Cho, Y. H. Lim, J. C. Seo, and Y. C. Hong, "Effects of environmental cadmium exposure on liver function in adults," Occupational \& Environmental Medicine, vol. 70, no. 4, pp. 268-273, 2013.

[9] M. Wallin, L. Barregard, G. Sallsten et al., "Low-level cadmium exposure is associated with decreased bone mineral density and increased risk of incident fractures in elderly men: the MrOS Sweden study," Journal of Bone and Mineral Research, vol. 31, no. 4, pp. 732-741, 2016.

[10] A. M. Igra, M. Vahter, R. Raqib, and M. Kippler, "Early-life cadmium exposure and bone-related biomarkers: a longitudi- nal study in children," Environmental Health Perspectives, vol. 127, no. 3, article 037003, 2019.

[11] B. Fagerberg, L. Barregard, G. Sallsten et al., "Cadmium exposure and atherosclerotic carotid plaques-results from the Malmo diet and Cancer study," Environmental Research, vol. 136, pp. 67-74, 2015.

[12] K. E. Deering, A. C. Callan, R. L. Prince et al., "Low-level cadmium exposure and cardiovascular outcomes in elderly Australian women: a cohort study," International Journal of Hygiene and Environmental Health, vol. 221, no. 2, pp. 347354, 2018.

[13] S. Grioni, C. Agnoli, V. Krogh et al., "Dietary cadmium and risk of breast cancer subtypes defined by hormone receptor status: a prospective cohort study," International Journal of Cancer, vol. 144, no. 9, pp. 2153-2160, 2019.

[14] L. Peng, Y. Huang, J. Zhang et al., "Cadmium exposure and the risk of breast cancer in Chaoshan population of Southeast China," Environmental Science and Pollution Research, vol. 22, no. 24, pp. 19870-19878, 2015.

[15] D. H. Han, H. J. Lee, and S. Lim, "Smoking induced heavy metals and periodontitis: findings from the Korea National Health and Nutrition Examination Surveys 2008-2010," Journal of Clinical Periodontology, vol. 40, no. 9, pp. 850858, 2013.

[16] P. Malara, J. Kwapuliński, B. Malara, and J. Drugacz, "Effect of passive smoking on the level of selected metals in deciduous teeth," Przeglad Lekarski, vol. 63, no. 10, pp. 1002-1006, 2006.

[17] M. Gonzalez, J. A. Banderas, A. Baez, and R. Belmont, "Salivary lead and cadmium in a young population residing in Mexico City," Toxicology Letters, vol. 93, no. 1, pp. 55-64, 1997.

[18] R. V. Caruso, R. J. O'Connor, W. E. Stephens, K. M. Cummings, and G. T. Fong, "Toxic metal concentrations in cigarettes obtained from U.S. smokers in 2009: results from the International Tobacco Control (ITC) United States survey cohort," International Journal of Environmental Research and Public Health, vol. 11, no. 1, pp. 202-217, 2014.

[19] M. W. Ashraf, "Levels of heavy metals in popular cigarette brands and exposure to these metals via smoking," The Scientific World Journal, vol. 2012, Article ID 729430, 5 pages, 2012.

[20] J. Liu, W. Qu, and M. B. Kadiiska, "Role of oxidative stress in cadmium toxicity and carcinogenesis," Toxicology and Applied Pharmacology, vol. 238, no. 3, pp. 209-214, 2009.

[21] M. M. Brzóska, M. Galazyn-Sidorczuk, M. Jurczuk, and M. Tomczyk, "Protective effect of Aronia melanocarpa polyphenols on cadmium accumulation in the body: a study in a rat model of human exposure to this metal," Current Drug Targets, vol. 16, no. 13, pp. 1470-1487, 2015.

[22] M. M. Brzóska, S. Borowska, and M. Tomczyk, “Antioxidants as a potential preventive and therapeutic strategy for cadmium," Current Drug Targets, vol. 17, no. 12, pp. 1350-1384, 2016.

[23] S. H. Ma, L. L. Zhang, and Q. Q. Jiang, "Protective effect of bioflavonoid morin on cadmium induced oxidative neuropathy," Biomedical Research, vol. 28, no. 3, pp. 1148-1154, 2017.

[24] S. Nemmiche, "Oxidative signaling response to cadmium exposure," Toxicological Sciences, vol. 156, no. 1, pp. 4-10, 2017.

[25] K. Jomova and M. Valko, "Advances in metal-induced oxidative stress and human disease," Toxicology, vol. 283, no. 2-3, pp. 65-87, 2011. 
[26] M. M. Brzóska, J. Rogalska, A. Roszczenko, M. GałażynSidorczuk, and M. Tomczyk, "The mechanism of the osteoprotective action of a polyphenol-rich Aronia melanocarpa extract during chronic exposure to cadmium is mediated by the oxidative defense system," Planta Medica, vol. 82, no. 7, pp. 621631, 2016.

[27] P. Kostecka-Sochoń and E. Dąbrowska, "Wpływ kadmu i/lub cynku na wybrane enzymatyczne parametry bariery antyoksydacyjnej w śliniance podjęzykowej szczura," Dental and Medical Problems, vol. 50, no. 3, pp. 282-290, 2013.

[28] P. Kostecka-Sochoń, B. M. Onopiuk, and E. Dąbrowska, "Protective effect of increased zinc supply against oxidative damage of sublingual gland in chronic exposure to cadmium: experimental study on rats," Oxidative Medicine and Cellular Longevity, vol. 2018, Article ID 3732842, 8 pages, 2018.

[29] M. Mężyńska, M. Brzóska, J. Rogalska, and A. Galicka, "Extract from Aronia melanocarpa L. berries protects against cadmium-induced lipid peroxidation and oxidative damage to proteins and DNA in the liver: a study using a rat model of environmental human exposure to this xenobiotic," Nutrients, vol. 11, no. 4, p. 758, 2019.

[30] M. Mężyńska, M. Brzóska, J. Rogalska, and B. PiłatMarcinkiewicz, "Extract from Aronia melanocarpa L. berries prevents cadmium-induced oxidative stress in the liver: a study in a rat model of low-level and moderate lifetime human exposure to this toxic metal," Nutrients, vol. 11, no. 1, p. 21, 2019.

[31] E. Czykier, B. Szynaka, and J. Dzięciol, “A preliminary study of the submandibular gland of the rat after one-year cadmium intoxication. Part II. Pathomorphology and ultrastructure," Roczniki Advances in Medical Sciences, vol. 49, Supplement 1, pp. 175-177, 2004.

[32] A. Zalewska, M. M. Brzóska, J. Marciniak, K. Karaszewska, K. Zwierz, and J. Moniuszko-Jakoniuk, "Activity of lysosomal exoglycosidases in submandibular glands of rats intoxicated by cadmium at doses related to human chronic environmental and occupational exposures," Acta Biochimica Polonica, vol. 51, no. 3, pp. 831-837, 2004.

[33] E. Dąbrowska, B. Szynaka, and E. Kulikowska-Karpińska, "Ultrastructural study of the submandibular gland of the rat after 6-month exposure to cadmium and zinc in drinking water," Advances in Medical Sciences, vol. 51, pp. 245-249, 2006.

[34] E. Dąbrowska, R. Letko, J. Łapińska, M. Szmitkowski, E. Kulikowska-Karpińska, and M. Brzóska, "Assessment of zinc concentration in the submandibular salivary gland of rat exposed to cadmium and/or zinc in drinking water," Polish Journal of Environmental Studies, vol. 19, no. 6A, pp. 80-85, 2010.

[35] S. Borowska and M. M. Brzóska, "Chokeberries (Aronia melanocarpa) and their products as a possible means for the prevention and treatment of noncommunicable diseases and unfavorable health effects due to exposure to xenobiotics," Comprehensive Reviews in Food Science and Food Safety, vol. 15, no. 6, pp. 982-1017, 2016.

[36] M. Mężyńska and M. M. Brzóska, “Związki polifenolowe w leczeniu i profilaktyce wybranych chorób cywilizacyjnych dowody z badań epidemiologicznych," Polski Przegląd Nauk o Zdrowiu, vol. 3, no. 48, pp. 269-276, 2016.

[37] M. Mężyńska and M. M. Brzóska, "Review of polyphenol-rich products as potential protective and therapeutic factors against cadmium hepatotoxicity," Journal of Applied Toxicology, vol. 39, no. 1, pp. 117-145, 2019.
[38] C. F. Gomes de Moura and D. A. Ribeiro, "Are food compounds able to modulate noxious activities induced by cadmium exposure?," Critical Reviews in Food Science and Nutrition, vol. 57, no. 3, pp. 632-636, 2017.

[39] S. Borowska, M. M. Brzóska, and M. Tomczyk, "Complexation of bioelements and toxic metals by polyphenolic compounds implications for health," Current Drug Targets, vol. 19, no. 14, pp. 1612-1638, 2018.

[40] K. Tawaha, F. Alali, M. Gharaibeh, M. Mohammad, and T. Elelimat, "Antioxidant activity and total phenolic content of selected Jordanian plant species," Food Chemistry, vol. 104, no. 4, pp. 1372-1378, 2007.

[41] S. E. Kulling and H. M. Rawel, "Chokeberry (Aronia melanocarpa) - a review on the characteristic components and potential health effects," Planta Medica, vol. 74, no. 13, pp. 1625-1634, 2008.

[42] A. Kokotkiewicz, Z. Jaremicz, and M. Łuczkiewicz, "Aronia plants: a review of traditional use, biological activities, and perspectives for modern medicine," Journal of Medicinal Food, vol. 13, no. 2, pp. 255-269, 2010.

[43] E. Şahin and S. Gümüşlü, "Immobilization stress in rat tissues: alterations in protein oxidation, lipid peroxidation and antioxidant defense system," Comparative Biochemistry and Physiology Part C: Toxicology \& Pharmacology, vol. 144, no. 4, pp. 342-347, 2007.

[44] H. Aebi, "[13] Catalase in vitro," Methods in Enzymology, vol. 105, pp. 121-126, 1984.

[45] A. Z. Reznick and L. Packer, "[38] Oxidative damage to proteins: spectrophotometric method for carbonyl assay," Methods in Enzymology, vol. 233, pp. 357-363, 1994.

[46] A. Cuypers, M. Plusquin, T. Remans et al., "Cadmium stress: an oxidative challenge," Biometals, vol. 23, no. 5, pp. 927-940, 2010.

[47] V. Domazetovic, G. Marcucci, T. Iantomasi, M. L. Brandi, and M. T. Vincenzini, "Oxidative stress in bone remodeling: role of antioxidants," Clinical Cases in Mineral and Bone Metabolism, vol. 14, no. 2, pp. 209-216, 2017.

[48] D. Miricescu, M. Greabu, A. Totan, A. Didilescu, and R. Rădulescu, "The antioxidant potential of saliva: clinical significance in oral diseases," Therapeutics, Pharmacology and Clinical Toxicology, vol. 15, no. 2, pp. 139-143, 2011.

[49] I. Lettrichová, L. Tóthová, J. Hodosy, M. Behuliak, and P. Celec, "Variability of salivary markers of oxidative stress and antioxidant status in young healthy individuals," Redox Report, vol. 21, no. 1, pp. 24-30, 2016.

[50] L.'u. Tóthová, N. Kamodyová, T. Červenka, and P. Celec, "Salivary markers of oxidative stress in oral diseases," Frontiers in Cellular and Infection Microbiology, vol. 5, p. 73, 2015.

[51] B. Onopiuk, P. Onopiuk, Z. Dąbrowska, E. Dąbrowska, M. Pietruska, and H. Car, "Effect of metronidazole on the oxidoreductive processes in the submandibular and parotid glands in experimental research," Oxidative Medicine and Cellular Longevity, vol. 2018, Article ID 7083486, 8 pages, 2018.

[52] T. Konopka, A. Gmyrek-Marciniak, Z. Kozłowski, U. Kaczmarek, and J. Wnukiewicz, "Potencjał antyoksydacyjny śliny u pacjentów z zapaleniem przyzębia i rakiem płaskonabłonkowym dna jamy ustnej," Dental and Medical Problems, vol. 43, pp. 354-362, 2006.

[53] B. Narotzki, Y. Levy, D. Aizenbud, and A. Z. Reznick, "Green tea and its major polyphenol EGCG increase the activity of oral peroxidases," in Respiratory Regulation - the Molecular 
Approach, M. Pokorski, Ed., vol. 756 of Advances in Experimental Medicine and Biology, pp. 99-104, Springer, Dordrecht, 2013.

[54] R. C. Patra, A. K. Rautray, and D. Swarup, "Oxidative stress in lead and cadmium toxicity and its amelioration," Veterinary Medicine International, vol. 2011, Article ID 457327, 9 pages, 2011.

[55] M. Bräunlich, R. Slimestad, H. Wangensteen, C. Brede, K. Malterud, and H. Barsett, "Extracts, anthocyanins and procyanidins from Aronia melanocarpa as radical scavengers and enzyme inhibitors," Nutrients, vol. 5, no. 3, pp. 663-678, 2013.

[56] P. N. Denev, C. G. Kratchanov, M. Ciz, A. Lojek, and M. G. Kratchanova, "Bioavailability and antioxidant activity of black chokeberry (Aronia melanocarpa) polyphenols: in vitro and in vivo evidences and possible mechanisms of action: a review," Comprehensive Reviews in Food Science and Food Safety, vol. 11, no. 5, pp. 471-489, 2012.

[57] S. Kulling and H. Rawel, "Chokeberry (Aronia melanocarpa) a review on the characteristic components and potential health effects," Planta Medica, vol. 74, no. 13, pp. 1625-1634, 2008.

[58] T. Jurikova, J. Mlcek, S. Skrovankova et al., "Fruits of black chokeberry Aronia melanocarpa in the prevention of chronic diseases," Molecules, vol. 22, no. 6, p. 944, 2017.

[59] L. P. Dai, X. J. Dong, and H. H. Ma, “Antioxidative and chelating properties of anthocyanins in Azolla imbricata induced by cadmium," Polish Journal of Environmental Studies, vol. 21, no. 4, pp. 837-844, 2012.

[60] S. Quideau, D. Deffieux, C. Douat-Casassus, and L. Pouységu, "Plant polyphenols: chemical properties, biological activities, and synthesis," Angewandte Chemie International Edition, vol. 50, no. 3, pp. 586-621, 2011.

[61] M. V. Walvekar, P. P. Sarvalkar, and S. B. Pol, "Modulatory effects of curcumin on antioxidative enzymes in submandibular gland of male mice during aging," International Journal of Pharma and Bio Sciences, vol. 4, no. 1, pp. 639-645, 2013. 


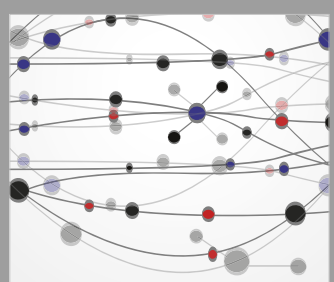

The Scientific World Journal
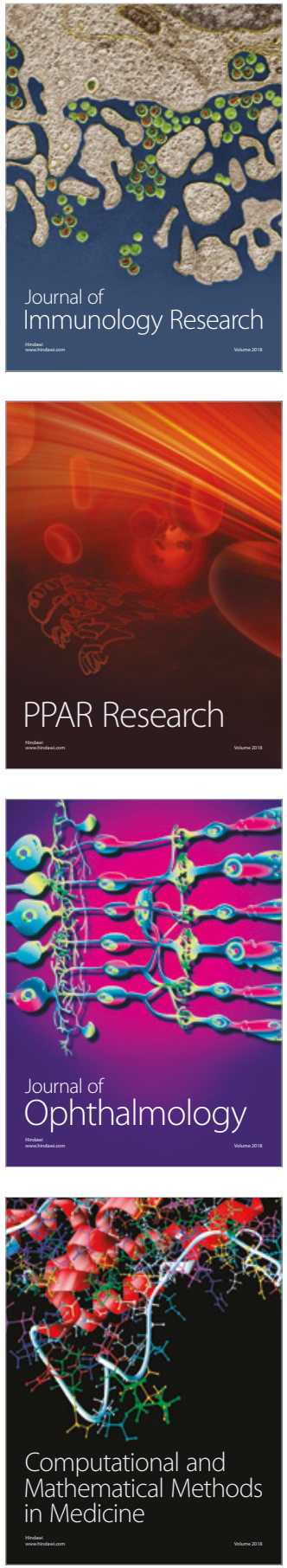

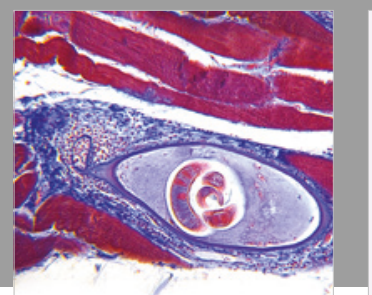

Gastroenterology Research and Practice

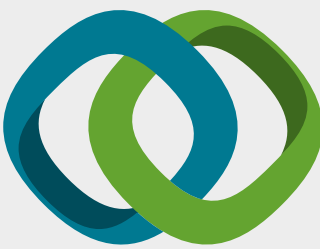

\section{Hindawi}

Submit your manuscripts at

www.hindawi.com
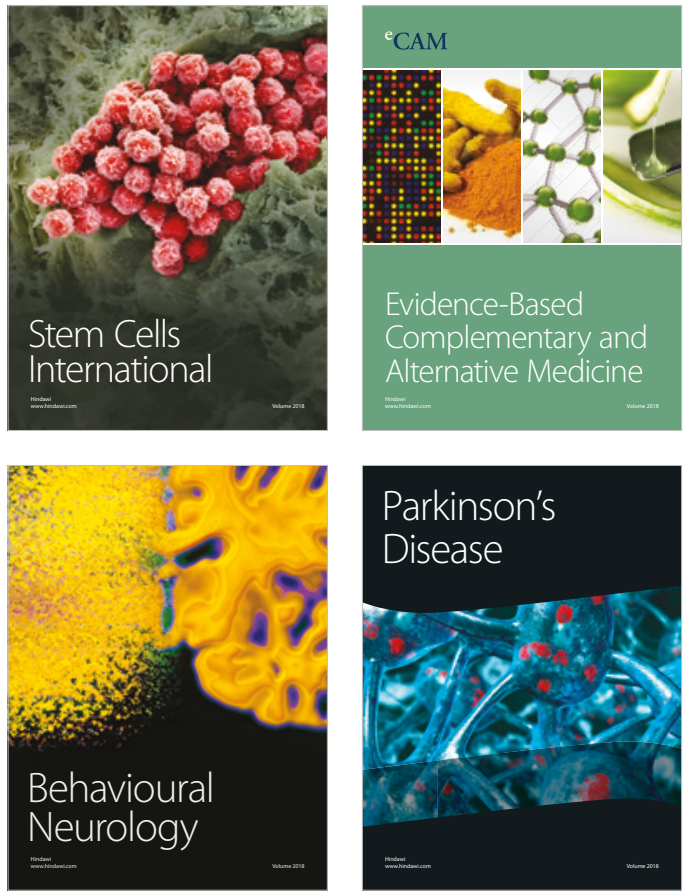

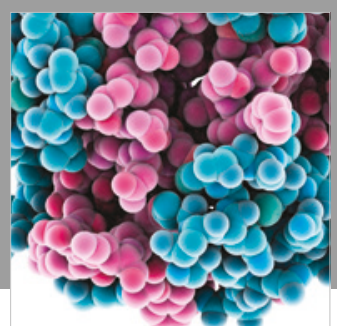

ournal of

Diabetes Research

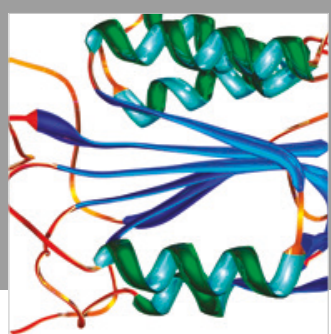

Disease Markers
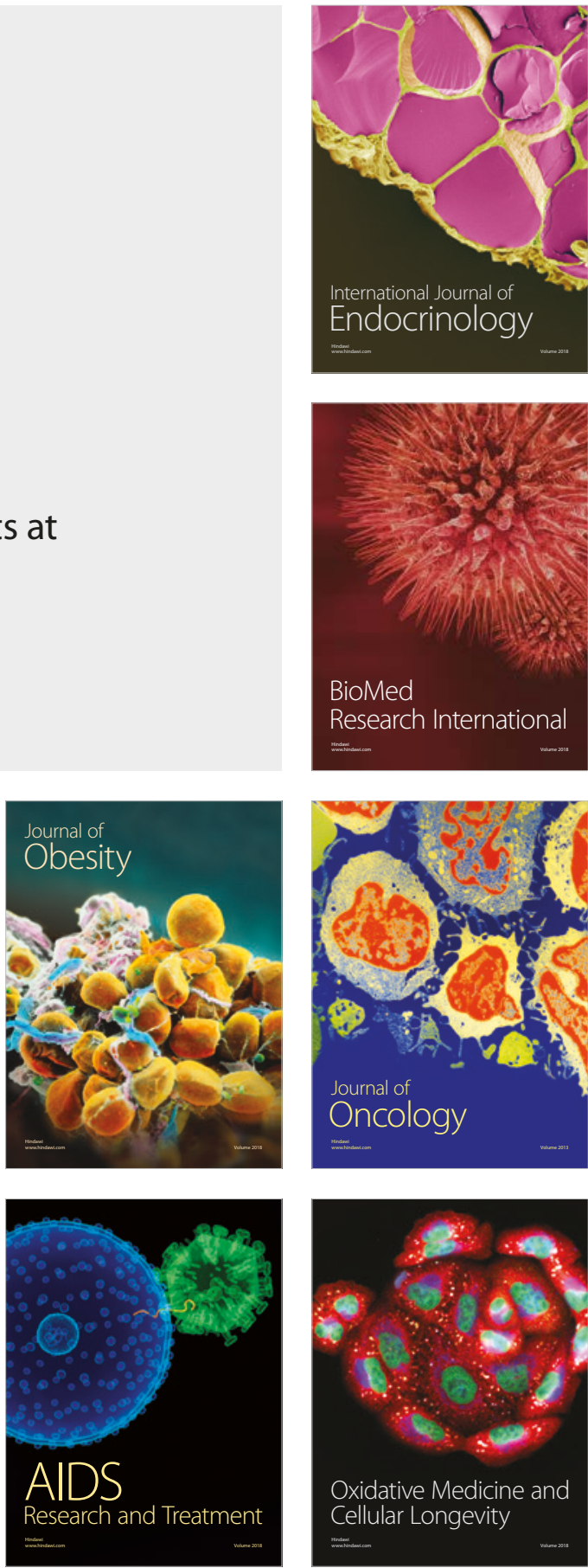